\title{
Consumer Activities and Reactions to Social Network Marketing
}

\author{
BISTRA VASSILEVA \\ University of Economics Varna, Bulgaria \\ bistravas@ue-varna.bg
}

The purpose of this paper is to understand consumer behavioural models with respect to their reactions to social network marketing. Theoretical background is focused on online and social network usage, motivations and behaviour. The research goal is to explore consumer reactions to the exposure of social network marketing based on the following criteria: level of brand engagement, word-of-mouth (wом) referral behaviour, and purchase intentions. Consumers are investigated based on their attitudes toward social network marketing and basic socio-demographic covariates using data from a sample size of 700 Bulgarian respondents (age group 21-54 years, Internet users, urban inhabitants). Factor and cluster analyses are applied. It is found that consumers are willing to receive information about brands and companies through social networks. They like to talk in social networks about these brands and companies and to share information as well (factor 2, brand engagement). Internet users are willing to share information received through social network advertising (factor 1, wo M referral behaviour) but they would not buy a certain brand as a result of brand communication activities in social networks (factor 3, purchase intention). Several practical implications regarding marketing activities through social networks are drawn.

Key words: social network marketing, social network behavioural models, brand engagement https://doi.org/10.26493/1854-4231.12.133-144

\section{Introduction}

During the last decades, the world is in a permanent state of change because of the rapid development of information technologies. Marketing practice is changing with the same pace while marketing academia is still lagging behind. Digital technologies are being integrated with marketing activities continuously or disruptively to reach Marketing 4.0, a new generation of marketing approaches, methods, tools, and practices (Jara, Parra, and Skarmeta 2012). This paper begins by outlining the challenges of social media (Web 2.0), 
followed by a discussion about behaviour of Internet users in social networks. In this study, the author undertakes a quantitative research process and applies factor analysis on collected through faceto-face interviews data. Research objectives driving this paper are: (1) to develop a demographic profile of Bulgarian online users and to identify their social network behavioural models; (2) to identify the factors shaping consumer reactions to various brand-related marketing activities in social networks and to determine corresponding clusters of investigated Internet users. Based on the achieved results several practical implications regarding related marketing activities through social networks are drawn.

\section{Challenges of Social Media Ecology}

The emergence of Internet-based social media has made it possible for one person to communicate with hundreds or even thousands of other people about products and the companies that provide them (Mangold and Faulds 2009, 357). Social media is defined as a group of internet-based applications that build on the ideological and technological foundations of Web 2.0, allowing for the creation and exchange of user-generated content (Kaplan and Haenlein 2010). Various social media applications are developed to facilitate Internet users interaction, which include blogs, content communities, discussion boards and chat rooms, product and/or service review sites, virtual worlds, and social networking sites (Kaplan and Haenlein 2010, 101; Mangold and Faulds 2009, 358). In this paper, we focus on social networks such as Facebook, Twitter, Google+, Instagram, and Pinterest. Internet-based communication, especially through social media, has become a major factor affecting various aspects of consumer behaviour and customer purchase decision-making (Ioanas and Stoica 2014). Digitalisation transforms the purchase decision-making process, including the way customers search for information, consider and evaluate products and services, interact with the organisation, and make purchases. Traditional customer purchase decision making has been transformed as a process into so called 'digital consumer decision journey' (van Bommel, Edelman, and Ungerman 2014).

Social media phenomenon leads to formation of unique social media ecology, consisting of a diverse set of social media sites, which vary in terms of their scope and functionality (Kietzmann et al. 2011, 241). Social networking sites form a substantial part of contemporary social media ecology. Some of them, like Facebook, are close to what we can call interactive crowd communication because it tar- 
gets all customers. Other social networking sites, like LinkedIn, are more focused professional networks. Twitter is a perfect example of real-time communication which continues to spread around the globe with more than 145 million users send on average 90 million 'tweets' per day, each consisting of 140 characters or less (Madway 2010).

Social media became an essential part of human life, which attracted the attention of marketers. Social media was adopted as important tool in today's hybrid inbound-outbound marketing communication mix. According to Kaplan and Haenlein $(2010,102)$ today's 'social media revolution' re-transforms the Internet back to its roots as a platform to facilitate information exchange between its users. Social media offer an unprecedented opportunity for marketers to search and analyse behavioural models of consumer communication and interaction in social networks to be able to develop proper marketing activities especially brand-oriented marketing communication campaigns.

\section{Methodology}

The research goal is to explore whether Internet users differ based on the following criteria: level of brand engagement, wом referral behaviour, and purchase intentions because of consumers' exposure to social network marketing. Two specific research objectives are defined. The first objective is to develop a demographic profile of Bulgarian online users and to identify their social network behavioural models. The second research objective is to identify the factors shaping consumer reactions to various brand-related marketing activities in social networks and to determine corresponding clusters of investigated Internet users. Consumers are investigated based on their attitudes toward social network marketing and basic socio-demographic covariates. Factor and cluster analysis are applied to analyse collected data.

\section{SAMPLING AND SURVEY METHOD}

Target population is limited to the age group from 21 to 54 years, Internet users, and urban inhabitants. Quota sampling method is used to form the sample. The sample is representative by gender, age, and place of living (according to the Gemius research in 2015, see Vassileva 2017). The sample size is 700 respondents with level of confidence of $95.0 \%$ and confidence interval of \pm 3.7 . The survey is administered through personal interview in respondents' homes in period 
from 22nd August to 7th September 2016. Data are processed using SPSS 21.0.

The questionnaire consists of three sections. The first section explores the behaviour of Internet users in social networks and their attitudes toward social networks. The questions in second section are designed to collect data about the attitudes of respondents toward brands with online presence and their reactions on brand-related marketing activities of the companies in social networks. Third section covers respondents' demographics.

\section{DEFINITION AND MEASUREMENT OF VARIABLES,}

RESEARCH MODEL

Four variables (gender, age, education, and monthly income of the household) are used as socio-demographic covariates in present research despite the controversial results about their influence on online customer behaviour (Campbell, Ferraro, and Sands 2014, 43942). Additional question regarding possession of mobile devices is included in questionnaire. It is used as covariate as well since smartphones are treated both as an 'extension' to the social media and as a tool to use social networks (Rheingold 2002).

In order to determine market positions of social networks in Bulgaria two indicators are used: social networks where respondents support an account and the first social network where respondents signed in. The experience of respondents with social networks is measured by the indicator 'duration of social network usage.' Social network usage intensity is determined by 'average daily usage (in minutes)' and number of contacts. Frequency of social network usage by type of activities is determined as well. Social network loyalty is measured by 'the most preferred social network' and 'the most frequently used social network' indicators. The influence of inboundoutbound brand-related marketing communications is determined by measuring the 'carry-over effect' of communication message from ATL to BTL channels.

The research model presented in figure 1 is used to determine the clusters of investigated Internet users regarding their reactions to various brand-related marketing activities in social networks.

Indicator variables (represented with dashed line on figure 1) are measured on a scale comprising seven items ( 3 for informational motivation, 2 for convenience motivation and 2 for entertainment motivation). Behaviour variables represent customer reactions to brandrelated marketing communication activities in social networks. They are measured on 22-item scale. The first 7 items (from item 2.1 to 


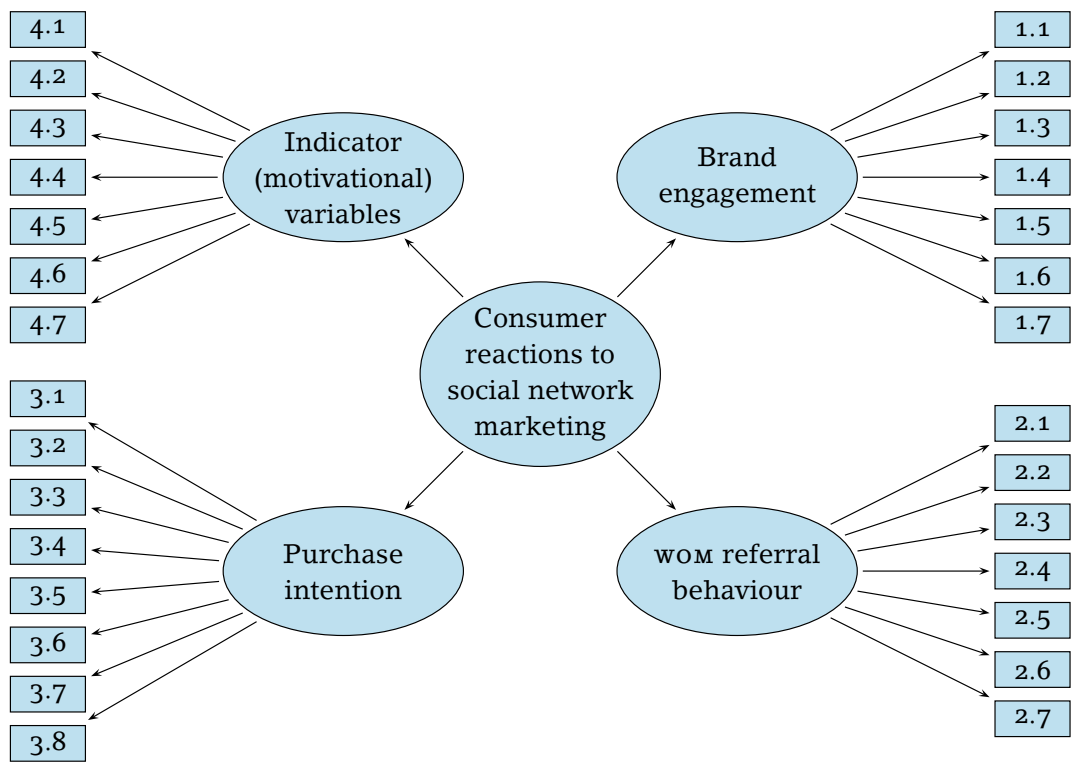

FIGURE 1 Research Model for Analysis and Evaluation of Consumer Reactions to Social Network Marketing

item 2.7 on figure 1) denote brand engagement, the next 7 items (from item 1.1 to item 1.7 on figure 1) indicate wom behaviour, and the last 8 items (from item 3.1 to item 3.8 on figure 1) express purchase intention. Seven-point Likert scale is used for all variables.

\section{Results and Discussion \\ DEMOGRAPHIC PROFILE OF BULGARIAN ONLINE USERS \\ AND THEIR SOCIAL NETWORK BEHAVIOURAL MODELS}

Approximately half of respondents (55.3\%) do not have children below 16 years in their households. More than $80 \%$ of respondents assess their wealth being as satisfactory (50.6\%), 32.4\% - as good, $3 \%-$ as bad, and $14 \%$ - as very bad. The average age of respondents is 37 years ( mean $=38$ years, median $=37$ years $)$.

Less than $1 \%$ of respondents do not possess a mobile device. The share of respondents who own smartphones is $78.9 \%$, followed by tablets $-50.6 \%$, mobile phones different from smartphones $-39.1 \%$, e-book readers $-15.7 \%$, and smart watches $-4.1 \%$. Facebook is the ultimate leader among social networks since $99.3 \%$ of respondents have an account there and approximately the same percentage $(88.6 \%)$ of respondents registered in Facebook as a first social 


\section{Bistra Vassileva}

TABLe 1 Demographic Profile of Respondents

\begin{tabular}{llr}
\hline Variable & Indicators & Percentage \\
\hline Age & $21-34$ years & 42.0 \\
& $35-44$ years & 32.6 \\
\hline Education & 45 -54 years & 25.4 \\
\hline Size of the household & Primary & 0.4 \\
& Secondary & 24.0 \\
& Upper secondary & 7.0 \\
& Bachelor/Master & 68.6 \\
\hline Gender & 1 person & $7 \cdot 7$ \\
& 2 persons & $23 \cdot 3$ \\
& 3 persons & $34 \cdot 3$ \\
Monthly household income (BGN) & 4 persons & 26.3 \\
& 5 persons and more & 8.4 \\
& Male & 49.3 \\
& Female & 50.7 \\
\hline
\end{tabular}

TABLE 2 Market Positions of Social Networks and Usage Level

\begin{tabular}{lrrrrrrr}
\hline$(1)$ & $(2)$ & $(3)$ & $(4)$ & $(5)$ & $(6)$ & $(7)$ & $(8)$ \\
\hline Facebook & 99.3 & 88.6 & 0.1 & 124.07 & 3 & 1080 & 86.7 \\
Google+ & 69.4 & 7.1 & 28.3 & 42.05 & 1 & 1440 & 8.1 \\
Twitter & 23.0 & 1.9 & 32.3 & 29.02 & 1 & 400 & 1.1 \\
Instagram & 24.1 & - & 16.6 & 22.00 & 1 & 120 & 0.9 \\
LinkedIn & 27.7 & 1.1 & 22.2 & 15.17 & 1 & 180 & 1.7 \\
Pinterest & 14.7 & - & 22.3 & 25.32 & 1 & 200 & 0.6 \\
\hline
\end{tabular}

Nотеs Column headings are as follows: (1) social network, (2) social network with account (\%), (3) first social network signed in (\%), (4) share of respondents with unused profile (\%), (5) average daily use (minutes), (6) minimum (minutes), (7) maximum (minutes), (8) most preferred social network (\%).

network. Google+ holds the second place, followed by LinkedIn (table 2).

Respondents use social networks mainly for communication purposes (to connect with the family and friends, $68.7 \%$ answered 'al- 


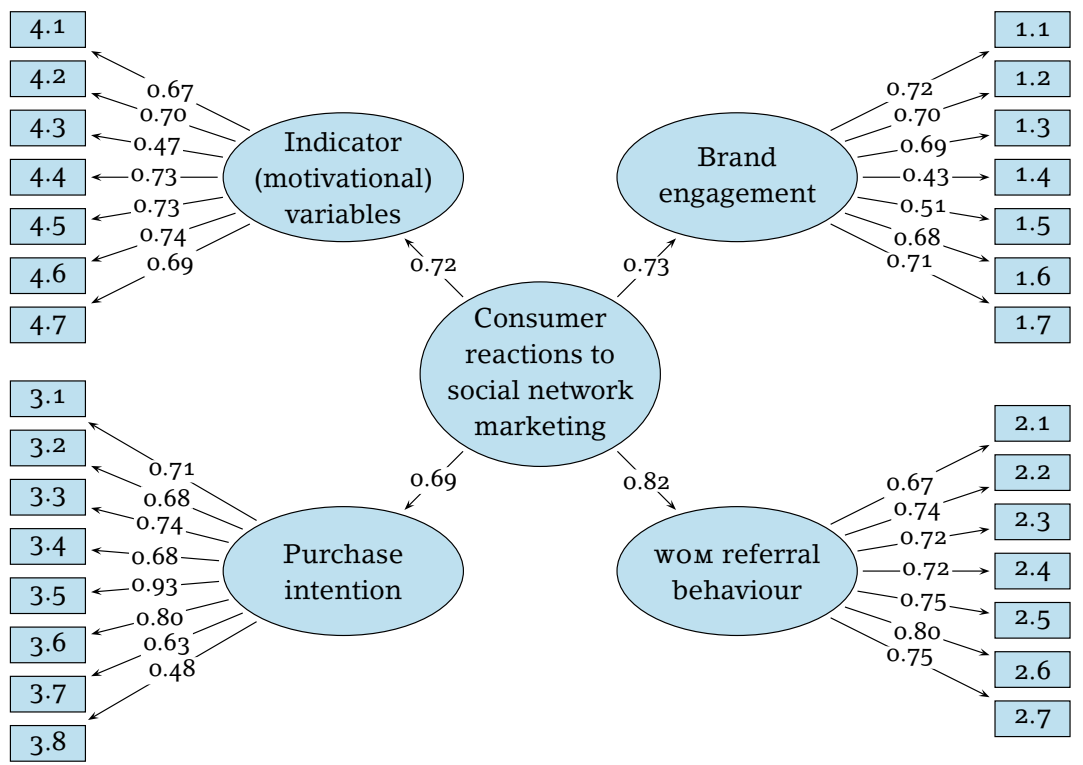

FIGURE 2 Research Model: Results from Factor Analysis

ways'), to search for information and news $(66.3 \%$ answered 'always'), and for entertainment (61\%). Social networks are seldom used for reviewing and sharing opinions. Approximately $40 \%$ of respondents maintain up to 200 contacts in their most frequently used social network. The relationship between the number of contacts and the social network with the highest usage intensity is statistically confirmed through $\chi^{2}$-test ( $p=0.0000$, weak correlation).

\section{REACTIONS TO SOCIAL NETWORK MARKETING}

Factor and cluster analysis are applied to analyse Internet users regarding their reactions to various brand-related marketing activities in social networks. The value of Kaiser-Meyer-Olkin Measure of Sampling Adequacy is 0.941. Bartlett's Test of Sphericity provides the following results: Approx. $\chi^{2}=14005.098$, Sig. $=0.000$. These results show an excellent sampling adequacy, which allows the conclusion that the items are consistent and form a measurement scale. The interpretation is done on Cronbach's alpha scale (the internal consistency is excellent for values equal or above o.9).

The results from the factor analysis are presented on figure 2. Factor extraction is performed using Principal Components Analysis. As table 5 shows, the substantial part of the change is caused by the first factor. 
TABLE 3 Results of Factor Analysis: Reliability Analysis (Behavioural Variables)

\begin{tabular}{|c|c|c|c|c|}
\hline Items & $(1)$ & $(2)$ & (3) & $(4)$ \\
\hline $\begin{array}{l}\text { I like to talk about brands/organizations that are adver- } \\
\text { tised on social networks. }\end{array}$ & 0.931 & & & 0.901 \\
\hline $\begin{array}{l}\text { I am always interested in learning more about } \\
\text { brands/organizations with online presence. }\end{array}$ & 0.936 & & & \\
\hline $\begin{array}{l}\text { I would be interested in receiving communications from } \\
\text { a brand/organization via social networks. }\end{array}$ & 0.957 & & & \\
\hline $\begin{array}{l}\text { I am accepting of communications from } \\
\text { brands/organizations providing they seek my permission. }\end{array}$ & 0.963 & & & \\
\hline $\begin{array}{l}\text { I am pleased to have others know which } \\
\text { brands/organizations I affiliate with via social networks. }\end{array}$ & 0.953 & & & \\
\hline $\begin{array}{l}\text { I like to browse through social networks related to } \\
\text { brands/organizations. }\end{array}$ & 0.961 & & & \\
\hline $\begin{array}{l}\text { Compared to other people, I closely follow news about } \\
\text { brands/organizations. }\end{array}$ & 0.963 & & & \\
\hline $\begin{array}{l}\text { I would share a social networking advertisement with } \\
\text { others if ... }\end{array}$ & & & & 0.935 \\
\hline $\begin{array}{l}\ldots \text { an advertisement offers a discount or coupon } \\
\text { for a particular product. }\end{array}$ & & 0.961 & & \\
\hline $\begin{array}{l}\text {... think that the advertised product would be useful } \\
\text { to someone I know. }\end{array}$ & & 0.951 & & \\
\hline ... the advertised product is quite easy to be used. & & 0.969 & & \\
\hline $\begin{array}{l}\ldots \text { the product solves a specific problem or issue that } \\
\text { is experienced by someone I know. }\end{array}$ & & 0.944 & & \\
\hline $\begin{array}{l}\ldots \text { an advertisement focuses on the positive benefits } \\
\text { of a product or service. }\end{array}$ & & 0.950 & & \\
\hline $\begin{array}{l}\ldots \text { an advertisement focuses on how to better deal with } \\
\text { a specific problem or issue. }\end{array}$ & & 0.950 & & \\
\hline $\begin{array}{l}\ldots \text { an advertisement mentions how other people are get- } \\
\text { ting good results from a product. }\end{array}$ & & 0.970 & & \\
\hline
\end{tabular}

Cluster analysis is applied using data from matrix rotation with six interactions. Six clusters are determined. The size of the smallest cluster is 43 persons $(6.1 \%)$, and the size of the biggest cluster is 189 persons $(27 \%)$.

Based on the analysis the following conclusions regarding forecasting importance of the factors are done. Factor 4 possesses the highest forecasting importance, while factor 3 the lowest. The items, which correspond to factor 4 after matrix rotation, are the following:

- I use social networking to learn about new and unknown things;

- I use social networking to learn about useful things;

- Social networks are easy for use;

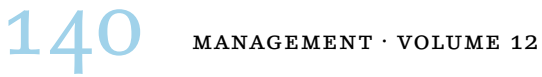


TABLE 3 Continued from the previous page

\begin{tabular}{|c|c|c|}
\hline Items & $(1)$ & (3) \\
\hline $\begin{array}{l}\text { I am likely to buy products that I see advertised on social } \\
\text { networks. }\end{array}$ & & $\begin{array}{lll}0.961 & 0.901\end{array}$ \\
\hline $\begin{array}{l}\text { I am likely to buy products that I see other consumers } \\
\text { talking about on social networks. }\end{array}$ & & 0.960 \\
\hline $\begin{array}{l}\text { I am likely to buy products that I see on social networks } \\
\text { if the price is appealing. }\end{array}$ & & 0.957 \\
\hline $\begin{array}{l}\text { I am likely to buy products that I see on social networks } \\
\text { if the delivery period is satisfactory. }\end{array}$ & & 0.967 \\
\hline $\begin{array}{l}\text { I am likely to buy products that I see on social networks } \\
\text { if it is a brand I know and trust. }\end{array}$ & & 0.959 \\
\hline $\begin{array}{l}\text { I am likely to buy products that I see on social networks } \\
\text { if it is a new product. }\end{array}$ & & 0.961 \\
\hline $\begin{array}{l}\text { I am likely to buy products that I see on social networks } \\
\text { if it is an exciting product. }\end{array}$ & & 0.938 \\
\hline $\begin{array}{l}\text { I am likely to buy products that I see on social networks } \\
\text { if it is an upgrade to a product I already have. }\end{array}$ & & 0.965 \\
\hline
\end{tabular}

Notes Column headings are as follows: (1) brand engagement, (2) woM, (3) purchase intention, (4) reliability (Cronbach alpha). The values of Cronbach's Alpha correspond to the set of items included in the respective complex scale. Items (statements) are adapted from Campbell, Ferraro, and Sands (2014).

TABLE 4 Results of factor Analysis: Reliability Analysis (Indicator Variables)

\begin{tabular}{|c|c|c|c|c|}
\hline Items & $(1)$ & $(2)$ & (3) & (4) \\
\hline $\begin{array}{l}\text { I use social networking to learn about new and unknown } \\
\text { things. }\end{array}$ & 0.854 & & & 0.759 \\
\hline I use social networking to learn about useful things. & 0.848 & & & \\
\hline $\begin{array}{l}\text { Social networks are a reliable source for information } \\
\text { about products/brands. }\end{array}$ & 0.969 & & & \\
\hline Social networks are easy for use. & & 0.804 & & 0.928 \\
\hline Social networks are convenient for use. & & 0.826 & & \\
\hline I use social networking to pass time. & & & 0.739 & 0.653 \\
\hline $\begin{array}{l}\text { I use social networking because I just like to browse } \\
\text { the internet. }\end{array}$ & & & 0.870 & \\
\hline
\end{tabular}

NOTES Column headings are as follows: (1) information motivation, (2) convenience motivation, (3) entertainment motivation, (4) reliability (Cronbach alpha). The values of Cronbach's Alpha correspond to the set of items included in the respective complex scale. Items (statements) are adapted from Campbell, Ferraro, and Sands (2014).

\section{- Social networks are convenient for use.}

The item 'I am likely to buy products that I see on social networks if it is a brand I know and trust' does not correspond to any of the factors. The separation of factor 5 with the following items: 'I use 
TABLE 5 Factor Analysis, PCA

\begin{tabular}{lrrrrrrr}
\hline \multirow{2}{*}{ Factor } & \multicolumn{3}{c}{ Initial values } & & \multicolumn{3}{c}{ Factor loadings (rotation matrix) } \\
\cline { 2 - 3 } \cline { 6 - 7 } & $(1)$ & $(2)$ & $(3)$ & & $(1)$ & $(2)$ & $(3)$ \\
\hline 1 & 11.976 & 41.295 & 41.295 & & 5.222 & 18.007 & 18.007 \\
2 & 2.403 & 8.288 & 49.582 & & 4.779 & 16.480 & 34.488 \\
3 & 2.182 & 7.523 & 57.105 & & 4.527 & 15.610 & 50.097 \\
4 & 1.583 & 5.458 & 62.563 & & 3.321 & 11.451 & 61.549 \\
5 & 1.323 & 4.561 & 67.125 & & 1.617 & 5.576 & 67.125 \\
\hline
\end{tabular}

Notes Column headings are as follows: (1) total value, (2) percentage, (3) cumulative percentage.

social networking to pass time' and 'I use social networking because I just like to browse the internet' represents an interesting result within the indicator variables.

The survey clearly demonstrates that consumers are willing to receive information about brands and companies through social networks. They like to talk in social networks about these brands and companies and to share information as well (factor 2, brand engagement). Internet users are willing to share information received through social network advertising (factor 1, wom referral behaviour) but they would not buy a certain brand as a result of brand communication activities in social networks (factor 3, purchase intention). The motivation to use social networks is related mainly to information about new and useful things, ease and convenience of use.

Regarding targeting opportunities of marketing communications through social networks the following conclusions could be useful. It was confirmed (ANOVA, $p=.003$ ) that there is a significant statistical relationship between the age group and the average daily usage (in minutes) of Facebook. Internet users from the age group 21-34 years spent on average 30 minutes more in Facebook than the age group 35-44 years and 45 minutes more than age group 45-54 years. This hypothesis was not confirmed for Google+, Twitter and LinkedIn but it was confirmed for Instagram $(p=.001)$ and Pinterest $(p=.013)$. For Instagram and Pinterest the direction of the relationship is contrary to Facebook. The usage levels raises with the increase of the age ( 5 minutes daily on average). The intensity of using social networks (average daily usage) increases with the duration of their use. It was confirmed for Facebook (ANOVA, $p=.004$ ) and Instagram (ANOVA, $p=.010)$. In four years' time span the average usage of Facebook raised with 86 minutes on a daily basis. The relationship between the gender and the daily usage of social networks was confirmed

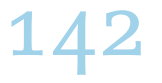


for Twitter $(p=.002)$, LinkedIn $(p=.002)$ and Pinterest $(p=.001)$. Women spend more time daily in Twitter and LinkedIn, while men spend more time in Pinterest. There is no difference between men and women for Facebook daily usage.

\section{Conclusions and Implications for Future Research}

The changing role of information and communication technologies in marketing poses a substantial challenge to both marketing academics and practitioners. Understanding customer behaviour is a complex task for marketing researchers especially in a digital environment. The research goal of presented study is to explore whether Internet users differ based on the following criteria: level of brand engagement, wom referral behaviour, and purchase intentions as a result of consumers' exposure to social network marketing. Consumers are investigated based on their attitudes toward social network marketing and basic socio-demographic covariates. Facebook is the ultimate leader among social networks with $99.3 \%$ of respondents having an account there and approximately the same percentage (88.6\%) of respondents signed in Facebook as their first social network. Google+ holds the second place, followed by LinkedIn. It becomes clear that brand-marketing activities of Bulgarian companies should focus on Facebook as a main communication channel.

The relationship between the number of contacts and the social network with the highest usage intensity (measured as average daily use in minutes) is statistically confirmed. This result confirms the importance of Facebook because it is the social network with the highest usage intensity in Bulgaria. The confirmed statistical hypothesis suggests that Facebook possess huge potential for wom referral behaviour.

The survey clearly demonstrates that consumers are willing to receive information about brands and companies through social networks. They like to talk in social networks about these brands and companies and to share information as well. Internet users are willing to share information received through social network advertising but they would not buy a certain brand because of brand communication activities in social networks. The motivation to use social networks is related mainly to information about new and useful things, ease and convenience of use.

Further detailed analysis of combined influence of hybrid inbound-outbound brand-related marketing communication on Internet users could be used to achieve a synergy effect through micro

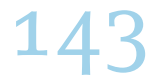


brand interventions. The author continues to work on segmentation of social media users by applying Latent class analysis (LCA) to determine the difference in their reactions to social network marketing activities.

\section{References}

Campbell, C., C. Ferraro, and S. Sands. 2014. 'Segmenting Consumer Reactions to Social Network Marketing.' European Journal of Marketing $48(3-4): 432-52$.

Ioanas, E., and I. Stoica. 2014. 'Social Media and its Impact on Consumers Behaviour.' International Journal of Economic Practices and Theories 4 (2): 295-303.

Jara, A. J., and M. C. Skarmeta. 2012. 'Marketing 4.o: A New Value Added to the Marketing through the Internet of Things.' In Proceedings of the 2012 Sixth International Conference on Innovative Mobile and Internet Services in Ubiquitous Computing, 852-7. Washington, DC: IEEE Computer Society.

Kaplan, A. M., and M. Haenlein. 2010. 'Users of the World, Unite! The Challenges and Opportunities of Social Media.' Business Horizons 53 (1): 59-68.

Kietzmann, J., K. Hermkens, I. McCarthy, and B. Silvestre. 2011. 'Social Media? Get Serious! Understanding the Functional Building Blocks of Social Media.' Business Horizons 54 (3): 241-51.

Madway, G. 2010. 'Twitter Remakes Website, Adds New Features.' Reuters, 14. September. http://www.reuters.com/article/ idUSN1411135520100915

Mangold, W., and D. Faulds. 2009. 'Social Media: The New Hybrid Element of the Promotion Mix.' Business Horizons 52 (4): 357-65.

Rheingold, H. 2002. Smart Mobs: The Next Social Revolution. Cambridge, MA: Basic Books.

Van Bommel, E., D. Edelman, and K. Ungerman. 2014. 'Digitizing the Consumer Decision Journey.' McKinsey\&Company, 14 June. http://www.mckinsey.com/business-functions/marketing-and-sales/ our-insights/digitizing-the-consumer-decision-journey

Vassileva, B. 2017. 'Marketing 4.o: How Technologies Transform Marketing Organisation.' Obuda University e-Bulletin 7 (1): 47-56.

This paper is published under the terms of the AttributionNonCommercial-NoDerivatives 4.0 International (CC BY-NC-ND 4.0)

License (http://creativecommons.org/licenses/by-nc-nd/4.o/). 